\title{
Escaping Shirley World Prison's Dirty Secret: The Special Management Unit Charles N. Diorio
}

$\mathrm{M}$ CI-Shirley's Special Management Unit (SMU) is a 60-man cell block. ${ }^{1}$ A bunker set apart from general population where prisoners charged with disciplinary infractions await action, ${ }^{2}$ this guarded place is where prisoners wait in administrative segregation for a disposition. It is a secret place where convicts unable to live in general population wait for a 'safe' situation to emerge within a cruel, unsympathetic system.

Recently, I spent 103 days in this hell. I punched a prisoner who insulted me and I was placed in SMU-2-25, a cell about ten-by-twelve with a window barred and covered by heavy steel mesh. On the walls was graffiti: "Don't overstay your welcome in Shirley World" and "Don't Give Away Your Power". I would soon come to feel that the prisoner who wrote these words shared a similar experience to my own.

I arrived on the last day of August. I had worked in SMU as a custodian or a "runner". I had been a guest in SMU in the past and expected my stay to be a simple relief from general population. I was given basic items like a radio and headphones from my personal property. I got some legal papers, underwear and socks, along with a blanket, sheet, pillow and little else. My mattress was standard issue and came with the cell. I expected a rest from the misery of general population. Sadly, what would happen to me would leave me shocked, dazed and confused.

SMU is a place where a person can feel lost and ignored. One is immediately struck by the painful disadvantage of having to communicate across a heavy metal door. Guards and administrators easily dismiss and ignore pleas from prisoners who bang on the steel sliding door and narrow glass that offers a limited view of the housing unit. It is easy to feel an officer's glare as evidence that they do not care about you or your concerns, and that your words are a joke.

It is the policy, and a law, here in Massachusetts to treat prisoners with kindness. In fact, the superintendents of institutions "under the supervision of the DOC [Department of Correction] shall treat prisoners with kindness which their obedience, good industry, and conduct merit". ${ }^{3}$

Prison life delivers disappointment directly and without pretense. It serves up with a shrug all the inhumanity people can deliver to one another. In MCI-Shirley, and I am sure many other segregation units across this nation that bear the name or not, the treatment is brutal, inhumane, silenced 
and carefully covered up. I would come to learn that the guards in the Special Management Unit at MCI-Shirley protect their jobs and prisoners remain entirely at their mercy. It is important to note that there are no rules of conduct posted in SMU. Yet, there are many rules. Most rules are simply customs developed over time, much like the convict code itself. However, breaking the unwritten rules of conduct in SMU can have dire consequences.

On the morning of 8 September 2015, just after the first major standing count of the day, I was offered two breakfast trays. This was unusual, but I accepted the offer from the officer. Little did I realize at the time was that by accepting two breakfast trays, I was effectively waiving my mandatory recreation yard privilege. Prisoners in segregation are permitted just one hour of recreation Monday to Friday.

As prisoners in solitary must be handcuffed behind their backs each and every time they are removed from their cells, this burden becomes a tedious task for guards who must "hook up" prisoners and escort them to a caged recreation deck behind the bunker. It occurred to guards that offering prisoners an additional food tray in exchange for not having to perform this burdensome exercise made perfect sense. I filed a grievance, where I asserted that "I was denied my one hour recreation" and "I did not request two trays". 4

As soon as I filed this grievance my days in SMU became a nightmare as I now faced cruel treatment and conditions of confinement. This grievance triggered a wave of retaliation that included loss of telephone privileges and character assassination. My requests for basic services like laundry and the law library were ignored, while my mail was tampered with, and my legal mail was read and taken from me. I was made to suffer verbal abuse, petty slights, and in the end, was locked in a cell behind a steel fire door which obstructed my view and where I would be passed by for books and other privileges.

Daily abuse forced me to write more grievances. I was disheartened and I could feel my spirit break. It was confusing that prison officers, supervisors, and administrators could behave in such an undisciplined and unprofessional manner. Guards in particular are emboldened to bad acts by a lack of adequate supervision and a sense their conduct will go unpunished. Government agents performing discretionary functions are generally shielded from liability for civil damages insofar as their conduct does not violate clearly established statutory or constitutional rights that a reasonable person would know. ${ }^{5}$ This immunity, along with a thick wall of 
silence covering up misdeeds, allows prison guards to mistreat prisoners as they see fit.

Each and every time I was removed from my cell, guards would search it. My property and papers would end up scattered. I would be missing legal mail and important papers relevant to my case. I would often return to my cell and find I had no toilet paper, no pen, no paper.

On 14 September 2015 I suffered chest pains and high blood pressure. I was taken to a nearby hospital. When I returned, my cell was again searched, my papers torn and scattered. Beyond these petty violations, I was missing magazines, books and a pair of headphones for a small radio I was permitted. Guards stole my headphones. They would become a gift to another prisoner, I thought.

When I returned from the hospital, I was paraded through the unit to shouting and yelling from cells: "Rat!" "Ripper!" "Skinner!" The last two ugly words are a common prison term for "Rapist". It seemed obvious that the guards put the prisoners up to hurling these insults at me. The lieutenant, sergeant and officers on duty seemed satisfied. They had created a dangerous situation for me. They virtually sealed my fate.

Each day brought more danger. Guards made it their mission to either ignore me or do something to hurt me. On 19 September 2015, a Saturday, I was removed from my cell by three officers for a "cell inspection", I was told. Again, my property was tossed and turned. Papers were taken. Legal work was read and taken. Notes on my conditions of confinement were removed. I felt my papers being picked clean. All the while, I was handled roughly. ${ }^{6}$

During this time in the Special Management Unit, I could not be sure if my food was tampered with. I could not be sure of many of the things I suspected were happening to me. This is the nature of being locked in a cell. I can only suspect from the treatment I was receiving that guards will stop at nothing to mistreat and abuse a prisoner they feel is "telling on them".

Other grievances followed. I filed grievances about the mail, about being denied the use of the telephone for legal calls, about being denied books. When the day shift lieutenant told me to "suck a dick", I grieved him. Some grievances made it to the officer in charge of prisoners' grievances, while others did not. I found that most of my outgoing mail was not being delivered. I grieved this too. ${ }^{7}$

Perhaps the only good news about doing time in SMU is the support I received from a few staff members, including a caseworker, a young and 
smart correctional program officer - a CPO. I also appreciated my mental health case worker who made daily rounds and, besides being sympathetic, helped me to make a few calls to my lawyer by pleading with the day shift supervisor and Captain-of-the-Guard. Monday through Friday during the day shift, a CPO and mental health official make rounds. It is a brief cellto-cell consultation that during my time in the 'hole' meant a great deal to me. During each visit, I told them what was happening with me. Each shook their heads, but there was little they could do.

On 23 September 2015, while on the SMU-2 recreation cage, I was assaulted. Days before the attack, I had hints and indications from other prisoners that something was going to happen to me. This is part of the terror of prison life. Prisoners who say, "I never saw it coming", are either lying to themselves or unwilling to look at the clues, which are usually all around. Days before I was sucker punched and beaten senseless, I was told, "Stop filing grievances". The young man who attacked me told me point blank prior to the incident that seemed to have been instigated and directed by correctional officers, "We got it good here, I'm gonna be down here a long time... you're filing grievances about guards giving extra trays is gonna screw it up for the rest of us". When he said this, I realized instantly that this man was feeling some kind of way - an angry, dangerous way.

Days leading up to the altercation, yelling voices from other cells screamed, "Rat!". I could also hear guards giving prisoners my name and saying, "If you don't get a second tray, it's because of 25 cell". Prisoners need little motivation to hate their fellow convicts. Prison officers who label a prisoner a "rat" or "skinner" will certainly be dealt with by fellow prisoners. Many prisoners are poorly educated and developmentally challenged. "Crash Test Dummies" is a term used here in prison for easily influenced and dim-witted individuals willing to believe anything they are told, who often run in packs and can be counted on to fight for any reason.

I was assaulted by a Crash Test Dummy - a man thirty years younger than me - who said, "Stop filing grievances", when he gave me a sucker-punch shot to my right ear that perforated my eardrum and sent me to Shattuck Hospital in Jamaica Plains with hearing loss. My face was bloody. Guards cheered. The lieutenant said, "Charles, you're leaking", as blood flowed onto the asphalt of the caged-in recreation deck. The assault was written up as a "fight". 8

Prisons despise scrutiny, and this incident was quickly and quietly covered up. "Move along folks, nothing to see here". I should have been 
removed to an outside hospital for an emergency room evaluation, but I was not. Instead, I was given a disciplinary report for "fighting". This document, along with all my other disciplinary reports, was taken from me weeks later when I was finally able to go to the hospital to see a specialist for my perforated ear drum. While at the hospital, officers from the 7-3 shift entered my cell, SMU-1-21, to conduct yet another search. Weeks later, a second, much cleaned-up and well-crafted version of the report was given to me. Brutality, silence and cover-ups - this is the formula which marks life in the MCI-Shirley Special Management Unit.

During my 103 days of segregation by another name from 31 August to 11 December 2015, I observed the banality of violence that is a daily occurrence in the SMU. For instance, I witnessed a guard punch a handcuffed prisoner, rush him down a steep set of stairs and throw him to the concrete floor. He was placed in a fetid, filthy cell for hours while his property was packedup. He was screaming for his medication, yet he was told he had "refused his medication" and treated accordingly. I too was denied medication on at least one occasion and the same line was used with me: "You refused your medication". On another occasion, I was overmedicated. In both cases, I filed a grievance.

I also observed a prisoner pepper-sprayed and pulled from his cell for refusing to return a lunch tray. This man's action did not warrant the extreme use of force we witnessed, but relying on force is official policy. "Owing to difficulties inherent in prison management, prison administrators enjoy broad discretion" from the courts "in the administration of prison affairs". 9

Guards and administrators are emboldened to mistreat prisoners with impunity, especially in isolated Special Management Units which are set far apart from the general population, units where superintendents rarely visit. In fact, during my 103-day stay, I witnessed the superintendent make rounds only two times. On the first occasion, it was days before a facilitywide audit in September 2015. The second occasion took place as part of a carefully choreographed tour she gave to dignitaries a few weeks later.

When an assistant deputy superintendent visits, they are often flanked by an area supervisor or lieutenant, or both. The recently arrived deputy superintendent in charge of the SMU is carefully controlled. She is escorted from cell to cell by both a sergeant and lieutenant for fear she may be told something unsettling about operations. This sheltering process is 
commonplace and is one that prevents communication with prisoners. For instance, amidst my 'fighting' ordeal and 'replaced' grievance, I tried to pass a letter to the deputy superintendent, who refused to take it during her rounds, because she was escorted by both a sergeant and lieutenant. Upon seeing her again, some three weeks later, I asked, "did you get my note?" She responded, "No, I don't think so". Add this to my mail, including from my attorney, being diverted, the grievances that were not officially filed, and the like, it was clear that I was being isolated.

All this was working against me, as was time. I was languishing in a solitary segregation cell and the means to defend myself were being stripped away. Beyond guards taking and 'replacing' them with carefully crafted reports that made it impossible to challenge or defend and my mail was being tampered with, I was denied timely access to medical reports and other evidence, including photographs of my broken nose and bloody face taken after the beating that were sitting in the office of the Inner Perimeter Security. I was also denied an opportunity to view any closed-circuit security video of the alleged "fight", which due to the way the security camera was directed - even if it was working, which I doubt it was - it may not have captured the attack.

In the end, the prison had no intention of producing any of the evidence I had requested. The disciplinary hearing process was and remains a joke. After six weeks of this pretentious farce where I endured harassment on a daily basis, I pled guilty, hoping to simply be reclassified far from MCIShirley. The matter was swept under the rug. I was given "time served". Once again, the behemoth - the creature known as the Department of Correction - won.

When I accepted a guilty plea for "fighting", I had been nearly 90 days in solitary. By law, "In no circumstances may an inmate be held in segregation awaiting action for longer than ninety-days without a hearing". ${ }^{10}$ Eventually, I had a classification hearing and was ordered transferred.

On 11 December 2015, I was finally told to pack my property. Just as swiftly as I was placed in segregation, I was removed from SMU and transferred to the Souza-Baranowski, a maximum-security correctional center just up the hill from Shirley World. 


\title{
ENDNOTES
}

1 The Special Management Unit is a separate housing area from general population within institutions where prisoners are confined - see 103 MGR 423.06 (2007).

2 The term "awaiting action" is used widely, yet is not codified. While frequently referenced to, there is no actual definition for the term (see LaChance v. Commissioner of Correction, 463 Mass. 767 - 8 May 2012).

3 See Mass. Gen. Law c. $127 \S 32$.

4 Grievance \#83401 was submitted on 8 September 2015. This document may be found in the appendix of Escaping Shirley World.

5 Harlow v. Fitzgerald, 457 U.S. 800, 818; 102 S. Ct 2727; 73 L. Ed. 2 d 396 (1982).

6 This was the first opportunity that I was able to watch and identify the officers' picking, reading, and taking my legal papers.

7 I filed a grievance against the lieutenant, however, I never received notice of the filing or a copy of the document. It would be one of numerous grievances that I wrote which were diverted.

8 Disciplinary Report \#348010 is the alleged "fighting" ticket.

9 See endnote 2.

10 See 103 Mass. Code Regulations 421.08(3)(1994).

\section{ABOUT THE AUTHOR}

Charles N. Diorio is a prisoner at MCI-Concord and can be reached at the following addresses below:

\author{
Charles N. Diorio \\ W103769 \\ MCI-Concord \\ PO Box 9106
}

Concord, Massachusetts 01742

USA

Attorney James J. Gavigan, Esq. 80 Billings Road

North Quinry, Massachusetts 02107

USA 